\title{
The context of unintended pregnancy among married women in the USA
}

\author{
Ainat Koren, Barbara Mawn
}

\begin{abstract}
Background and methodology Unintended pregnancy is a concern in the USA due to its association with adverse physical, mental, social and economic outcomes. Few studies have examined this issue among married women from a social and contextual perspective. This study targeted married women to examine factors associated with unintended pregnancy using the ecological model of health promotion that focuses attention on both individual and social environmental factors. Data from the National Survey of Family Growth (NSFG) were merged with NSFG contextual files to examine the major predictive factors.
\end{abstract}

Results Multilevel logistic regression modelling revealed that married women of lower socioeconomic status, higher parity, who lived in communities with a high rate of marital dissolution had a higher probability of an unintended pregnancy. Women reported that their husbands were likely to concur with the unintended designation of the pregnancy.

Discussion and conclusions This study utilised a unique perspective to examine contextual factors related to unintended pregnancy among married women. The results support the need to focus on the couple as a unit for prevention efforts. Social policies to enhance access to family planning services are necessary to improve outcomes and prevent unintended pregnancies.

Keywords ecological model, family planning education, health promotion, married women, unintended pregnancy

J Fam Plann Reprod Health Care 2010; 36(3): 150-158 (Accepted 27 April 2010)

\section{Introduction}

Reduction in the rate of unintended pregnancy in the USA is a national health priority. Progress in the reduction of unintended pregnancy has been difficult to achieve among women of childbearing ages. The Centers for Disease Control (CDC) reported that in 1995, $48 \%$ of all pregnancies were not intended; by 2002 the percentage of unintended pregnancies slightly increased to $49 \% .^{1}$ Although the rates remained stable, disparities have been noted in terms of race, age, marital status and socioeconomic status. ${ }^{2}$ The national Healthy People 2010 target for the general population of women in the USA for intended pregnancies, set at $70 \%, 3$ will not be met.

Unintended pregnancy is associated with significant and costly physical, psychological and socioeconomic risks to both mother and child.4,5 Children born as a result of an unintended pregnancy are more likely to be premature, have a low birth weight, and are at increased risk for child abuse. 2,6,7 Women who experience an unintended pregnancy are more likely to have inadequate prenatal care, ${ }^{7}$ a lower educational level, and live in poverty. ${ }^{2,8}$

Although unintended pregnancy is higher among unmarried women, little attention has been paid to the significant and unique concerns that are experienced by married women. Among married women, approximately $27 \%$ have reported an unintended pregnancy in the 2002 survey. Among married women, there has been little improvement since 1995 when the unintended pregnancy rate was $28 \% .^{1}$ Explanations as to why married women have not made significant progress in the reduction of unintended pregnancy are unclear.

School of Health and Environment, University of

Massachusetts, Lowell, MA, USA

Ainat Koren, PhD, Assistant Professor

Barbara Mawn, PhD, Nursing Program Director, Professor, and Co-Director of the Center for Health Promotion and Research, University of Massachusetts

Correspondence to: Dr Ainat Koren, School of Health and Environment, University of Massachusetts Lowell, 3 Solomont Way, Suite 2, Lowell, MA 01854-5126, USA.

E-mail: ainat_koren@uml.edu

\section{Key message points}

- Unintended pregnancy is a complex construct associated with individual disparities as well as other social and economic factors.

- The ecological model of health promotion provides a holistic approach to unintended pregnancy but due to its complexity not all levels of the model were predictive of unintended pregnancy among married women.

- Policies that support the inclusion of the spouse in family planning education need to be implemented in order to enhance the couple's ability to manage their reproductive health.

Researchers at the Emory Center on Health Outcomes and Quality9 reported that one-third of the unintended pregnancies among the 1173 births examined in this study occurred among married, educated and commercially insured women. Only $40 \%$ of the women with unintended pregnancy reported using contraception at the time of the study. Goldsmith et al. ${ }^{10}$ also examined knowledge of emergency contraception in a population-based sample of women in Oregon. The majority (69.5\%) of the sample included married women. They noted that lack of knowledge about emergency contraception was associated with unintended pregnancy when controlled for marital status and age.

\section{Theoretical model}

While multiple factors have been studied in relation to unintended pregnancy, they have been examined in isolation and the knowledge base has been limited to teen pregnancy, non-marital childbearing and other high-risk populations. Limited research has been done among married women and unintended pregnancy. Also, studies had observed pregnancy intendedness by looking at limited independent variables and were not theory driven. Those that were theory based focused on models of behaviour focus and on one dimension of health promotion, such as knowledge, attitudes or skills. Few studies have used one of the ecological models to explain or predict unintended pregnancy among married women. Moreover, limited research has been done to explore the influence of the environment on unintended pregnancies. 
McLeroy and associates ${ }^{11}$ developed an ecological model for health promotion that links health promotion strategies that target individual behaviours and environmental influences. The ecological model consists of five levels of analysis related to health behaviours and potential interventions. ${ }^{12}$ The intrapersonal level of the ecological model includes an individual's knowledge, attitudes, values, skills, behaviour, self-concept and beliefs. The interpersonal level encompasses social networks, social supports, families, peers and neighbours. The institutional level includes rules regulations and informal structures that may influence behaviour. The community level is comprised of community resources, neighbourhood organisations, and social and health services. The public policy level constitutes relevant legislation, policies and regulatory agencies.

\section{Unintended pregnancy in an ecological perspective: background Intrapersonal factors}

Unintended pregnancies occur among women of all socioeconomic levels and all marital statuses and age groups. Women under the age of 20 or older than 40 years, who are poor, with less than high school education and of African American race are especially likely to become pregnant unintentionally however. ${ }^{2,4,5}$ Poverty is strongly related to greater difficulty in using reversible contraceptive methods successfully; these women are also the least likely to have the resources necessary to access family planning services and the most likely to be affected negatively by an unintended pregnancy. ${ }^{3}$ Data from the 2001 NSFG showed that low-income women had much higher rates of unintended pregnancy than did wealthier women and that the disparity had increased since $1994 .^{2}$ This disparity might reflect health insurance coverage disparities where poor women are twice as likely to have no health insurance as compared to all women. ${ }^{13}$

Several studies that have explored how religious affiliation affects contraceptive use revealed significant differences in contraceptive use styles among Catholics, Protestants, Jews and those of no religious affiliation. Differences were hypothesised to be in relation to social norms, differential sex roles, male-female communication patterns, and the differential use of physician-based versus other sources of contraceptives. ${ }^{14,15}$ Other studies found little difference among Protestants, Catholics and Jews in overall contraceptive prevalence. However, Protestants relied more heavily on tubal sterilisation than on other methods, while Catholics were more likely to use the pill and Jews were more likely to use the diaphragm. 16

The effect of childhood abuse and household dysfunction on women's sexual behaviour continues from adolescence to adulthood. Women who suffered frequent psychological or physical abuse were significantly more likely to have an unintended first pregnancy than those women who did not. ${ }^{17}$

\section{Interpersonal factors}

Numerous studies support the notion that a woman's partner may have a major impact on her use or non-use of contraceptive method. Miller ${ }^{18}$ showed that, among married women, dislike by the husband of a method being used was significantly associated with an increased incidence of subsequent non-use. Acceptability of the mother's pregnancy intention was highly associated with the partner's attitude towards the pregnancy.9,19,20

\section{Institutional factors}

Proper use of contraceptive technologies for fertility regulation is linked to the availability of quality contraceptive services providing a full range of safe, approved methods of contraception. The literature reported the risk of unintended pregnancies to be associated with the failure of contraceptive methods, non-use of contraceptive methods, and lack of knowledge about contraceptive options, ${ }^{21}$ suggesting limited access to family planning counselling and the influence of the cost of contraceptives. ${ }^{4}$

\section{Community factors}

A multilevel analysis of marital and non-marital fertility in the USA found that for married women the contextual factors that affect the likelihood of a birth include the extent of full-time female labour force participation, the percentage of white-collar workers, and the percentage of females in the community who are separated or divorced. In contrast, the contextual variables that affected out-of-wedlock birth included: female unemployment rate; median housing value; percentage of females separated or divorced; percentage of females at childbearing age; sex ratio of the never married population; and the child/woman ratio for women aged 15-24 years. ${ }^{22}$ Community characteristics associated with higher levels of contraceptive effectiveness included rapid population growth, high socioeconomic status, and accessibility to family planning information and services. Community liberality, as measured by voting patterns, was negatively associated with effective contraceptive use. ${ }^{23}$

\section{Public policy}

The political atmosphere surrounding the years 1980-1991 is reflected by policy decisions that were not in favour of women who wanted to control their fertility and space their births. Although it was a time of new contraceptive developments and advances, they were not available to most of the target population. The media predominantly portrayed negative coverage by reporting mainly the complications of various forms of contraception. Funding was cut for family planning services and the services themselves were restricted. In the year 2000, the Department of Health and Human Services announced increasing private sector insurance coverage of contraceptives as an official public health goal. ${ }^{24}$ Since then, considerable progress toward the goal has been achieved; yet half of the women of reproductive health live in states where there is no such mandate. Moreover, the mandate relates to employees who are covered through employers who purchase health insurance and not to employees who work for employers who self-insure. ${ }^{24}$ Health insurance continues to be a barrier for women's reproductive health. A high percentage of poor women have no health insurance. In addition, federal spending under Title $\mathrm{X}$ declined between 1994 and 2001.13 [NB. Title X is the USA's federal grant programme dedicated solely to providing individuals with comprehensive family planning and related preventive health services. The Title X programme is designed to provide access to contraceptive services, supplies and information to all who want and need them. By law, priority is given to persons from low-income families. ${ }^{25}$ ]

Given the dearth of research examining factors associated with unintended pregnancy among married women, the purpose of the present study was to examine the contexts in which unintended pregnancy occurs in this group. The proposed original model (Figure 1) based on McLeroy et al.'s ecological model of health promotion guided the study. ${ }^{11}$ 


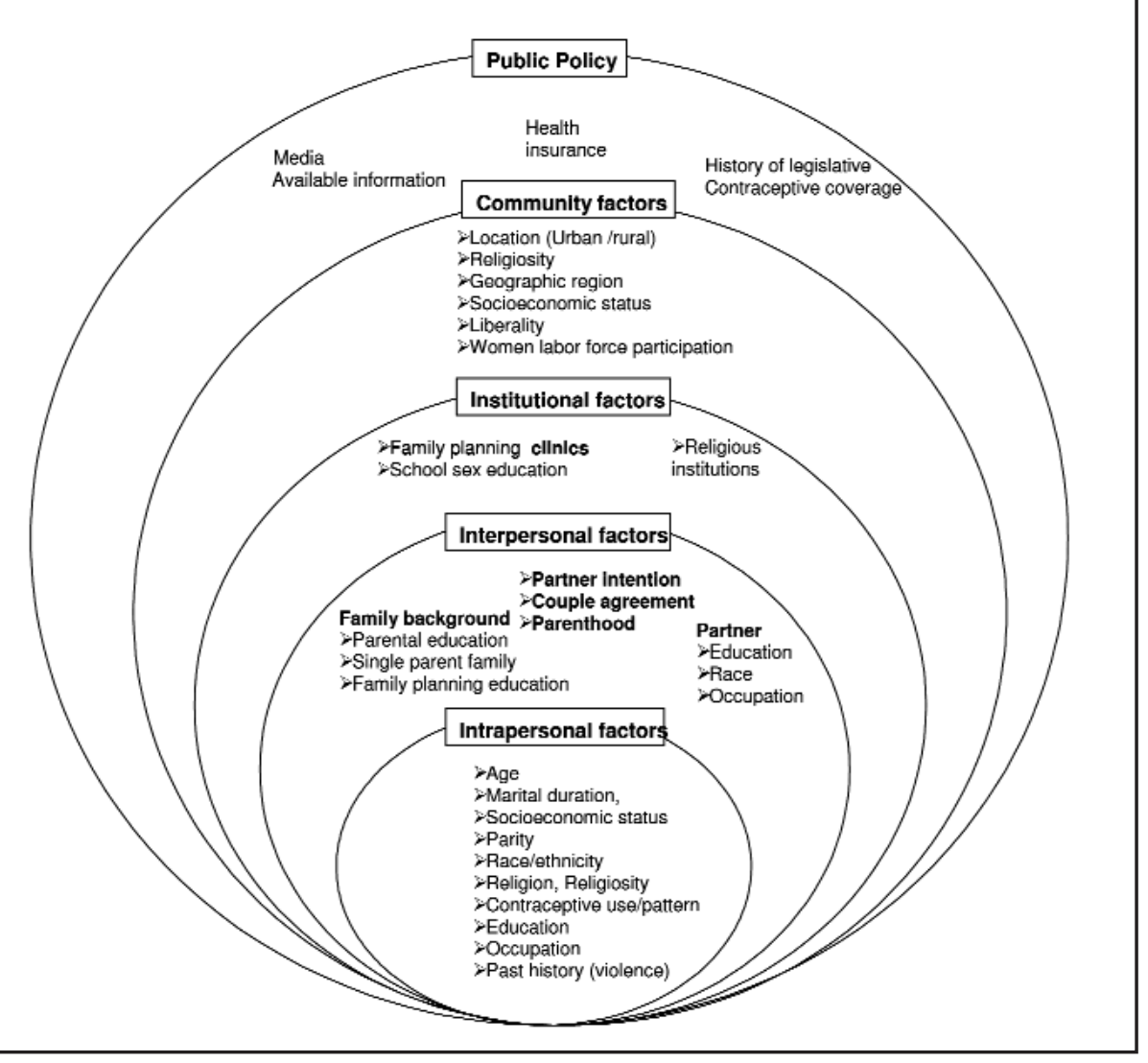

Figure 1 An ecological model of factors influencing unintended pregnancy in married women. Figure developed by Ainat Koren based on the general socioecological model for health promotion by McLeroy et al. ${ }^{11}$

\section{Methods}

The study design was a secondary data analysis of the fifth cycle of the NSFG merged with contextual data available through the CDC. This study was approved by the Institutional Review Board at the University of Massachusetts Lowell and the CDC Research Data Center.

The NSFG is a population-based survey of women, aged 15-44 years, from the civilian non-institutionalised sector of the USA. The NSFG surveys women every 3 to 7 years on sexual activity, contraceptive use, family planning, pregnancy intention, marriage and cohabitation, and infertility. ${ }^{26}$ At the time of this analysis, data were not yet available for the sixth (2002) and seventh (2006-2008) data collection; thus this study analysed the 1995 NSFG dataset. An analysis of the seventh cycle data is planned to examine differences among the identified contextual factors from 1995 to 2006 . This study incorporated factors from the first four levels of the socioecological model. The fifth level, public policy (i.e. the sociopolitical context in which the unintended pregnancies occurred) is described as the background for this study.

Inclusion criteria for this study included women from the USA who: were between the ages of 18 and 44 years at the time of pregnancy conception; gave birth between the years 1985 and 1995; and were married at the time of conception. The contextual NSFG data were available for the women's addresses during the calendar years 1990, 1993 and 1995. To satisfy the match between the timing of pregnancy conception with the timing of the contextual data collected and the women's address at the time the pregnancy occurred, individual level data were merged with the 1990 address and then matched to the NSFG 1995 contextual data. The sample was limited to include pregnancies that were conceived between the years 1985 and 1995. The sample for this study included 5936 pregnancies among 3384 married women.

Definitions of pregnancy intention vary. Often the terms 'unplanned pregnancy' and 'unintended pregnancy' are used interchangeably. For the purpose of the study, a recoded variable created by the NSFG data analysers was adopted. The dependent variable, intendedness of pregnancy, was defined as a dichotomous variable classified as unintended or intended pregnancy at the time of conception. To operationalise this concept, in the survey each woman was asked to think back to the time when she became pregnant. If a woman responded that, at the time she became pregnant, she did not want any more children, that pregnancy was classified as unwanted. If the woman reported instead that she did want a child in the future, she was asked whether that pregnancy occurred too soon, too late or at about the right time. Pregnancies that occurred too soon or were unwanted are classified as unintended, while those that occurred at about the right time or too late are considered intended. 5

The independent variables included seven intrapersonal indicators: age at conception, parity, race/ethnicity, education, religious affiliation, exposure to sexual violence and poverty level income. Two main interpersonal variables included were family background and husband's demographic factors such as race, education, religious affiliation, and pregnancy intendedness. Family background included both the woman's father's education and intact status of her childhood family. The husband's pregnancy intendedness was based on the woman's recollection of her husband's pregnancy intendedness.

The availability of family planning services within the county of residence was chosen as an institutional level variable from the NSFG contextual data set. Another indicator for the presence of institutions in the community was the number of abortions per 10000 women between the ages of 15 and 44 years. Predictive community level factors were divided into general categories: place of residence and community marital status at the county level. The place of residence was classified into: central cities of metropolitan areas, suburban areas and non-metropolitan areas. Community marital status was measured by the proportion of women who were separated or divorced. 


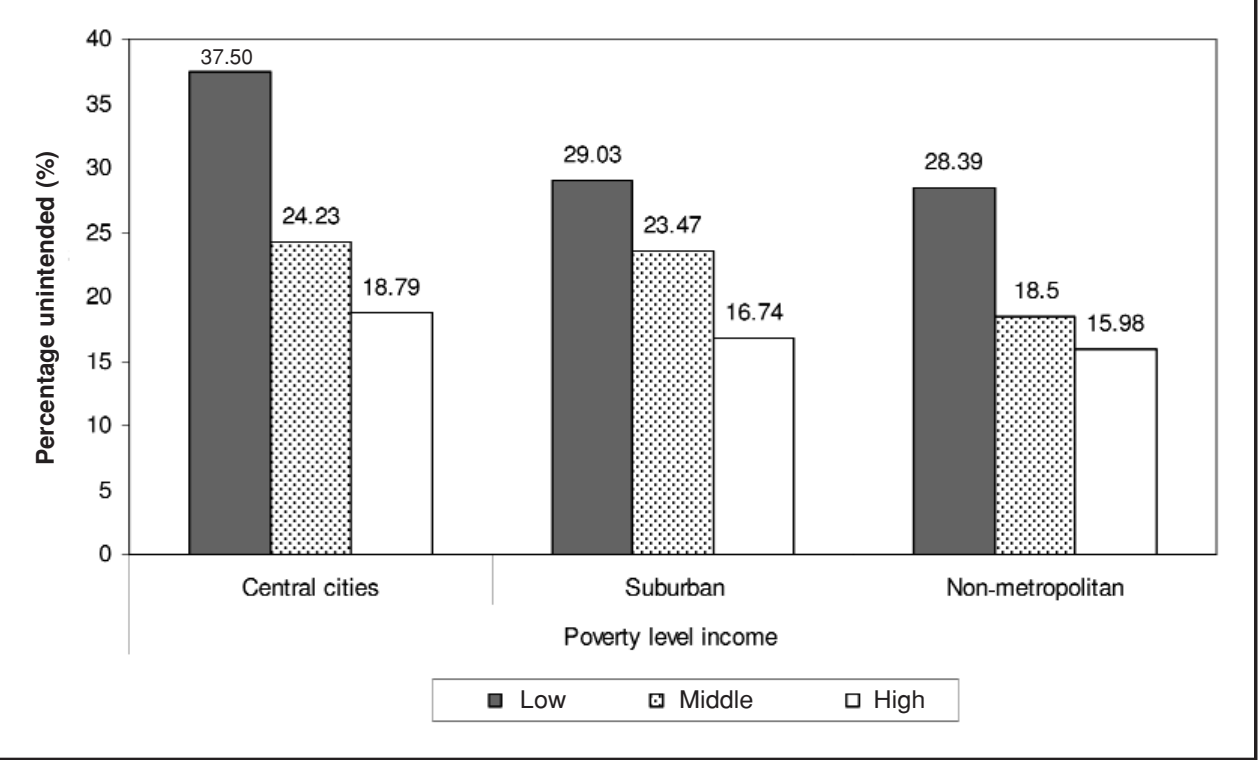

Figure 2 Percentage of unintended pregnancy among married women between the ages of 18 and 44 years by poverty level income and place of residence. $p<0.0001$

\section{Statistics}

The data were analysed using SAS version 8.12 (SAS Institute Inc, Cary, NC, USA). As a preparation for the multivariate analysis, several statistical procedures such as the Chi square test, correlation tests and the CochranMantel-Haenszel statistical test were used to assess bivariate associations between the dependent variable (unintended pregnancy) and the variables chosen to represent the different levels of the ecological model. The contextual county level variables were selected after extensive preliminary analysis and based on the literature. Several aggregate level variables were correlated with each other so that some of these variables could not enter into the same statistical model at once. This happened especially when the researchers introduced contextual variables that could stand as a proxy for socioeconomic indicators such as female unemployment rate and community education status. Since multicollinearity may lead to unstable estimates with large sample errors, only one representative variable per theoretical model level was introduced during the process of multilevel modelling (Appendix 1 shows the results from the bivariate analysis.)

For multivariate analyses, SAS PROC NLMIXED 27 procedure was used to estimate the effects of the dimensions of individual and community characteristics on unintended pregnancies among married women. Two levels of data aggregation - individual and county level -were included in analysis. Because individuals are nested within regional contexts (counties used for this analysis), a multilevel model was a preferable choice. These models may be more realistic than models assuming that county characteristics have either no effect, or a constant effect on the probability of having an unintended pregnancy. ${ }^{20}$

In this analysis, all regression coefficients other than the intercept are constrained to be fixed across the county units based on the assumption that the effect of the explanatory variables does not differ between counties. A two-step analysis approach advocated by Raudenbuch and $\mathrm{Bryk}^{28}$ was used. In a first stage of model building, models with only individual effects were estimated. Consequently in the second stage, models with both individual and county variables were estimated due to the fact that several contextual level variables were correlated with each other.

\section{Results}

Table 1 describes selected characteristics of women in this study. The table represents the weighted percentages that adjust for different sampling rates, response rates and coverage rates so that accurate national estimates can be made from the sample. The mothers were mainly of nonHispanic white origin $(65 \%)$. Ninety-eight percent were married at the time of giving birth. Seventy-six percent of the pregnancies were intended. This is comparable to the percentage of unintended pregnancies described by Henshaw. ${ }^{29}$

A significant association between pregnancy intendedness and place of residence while controlling for poverty level income was noted $(p<0.0001)$ (Figure 2). Women living in central cities with a lower income had a higher percentage of unintended pregnancies compared to women residing in the suburban and nonmetropolitan/rural areas belonging to a lower socioeconomic status. In addition, there was a significant association between the proportion of women separated or divorced in the community and unintended pregnancy while poverty level income was controlled for $(p<0.0001)$. Women living in communities with a higher divorce rate and a lower socioeconomic level had the highest percentage $(37.18 \%)$ of unintended pregnancies (Figure 3 ).

Table 2 summarises the results from the multivariate analysis. The first model shows variability across counties for pregnancy intendedness and therefore justifies the application of this statistical method (Table 2, Model 1). In the second model (Table 2, Model 2) the researchers introduced the intrapersonal and interpersonal level variables. The coefficients exhibited the predicted pattern consistent with the literature. Non-Hispanic white women of higher socioeconomic level and lower parity had a lower probability of an unintended pregnancy. The intact status of the childhood family and the experience of forced sex was a significant predictor as well but only in this model. Age at conception was not significant. This pattern followed throughout the models.

The third model (Table 2, Model 3) introduced the husbands' characteristics such as race, religion, education and pregnancy intention in addition to the community level variable, the place of residence. Both were individual level variables. The husband's race and perceived pregnancy intendedness showed a significant association with the probability of unintended pregnancy. As with the women, a non-Hispanic white husband had a lower probability of unintended pregnancy. The husband's positive pregnancy intendedness is significantly associated with the woman's positive pregnancy intendedness. The final model, Model 4 


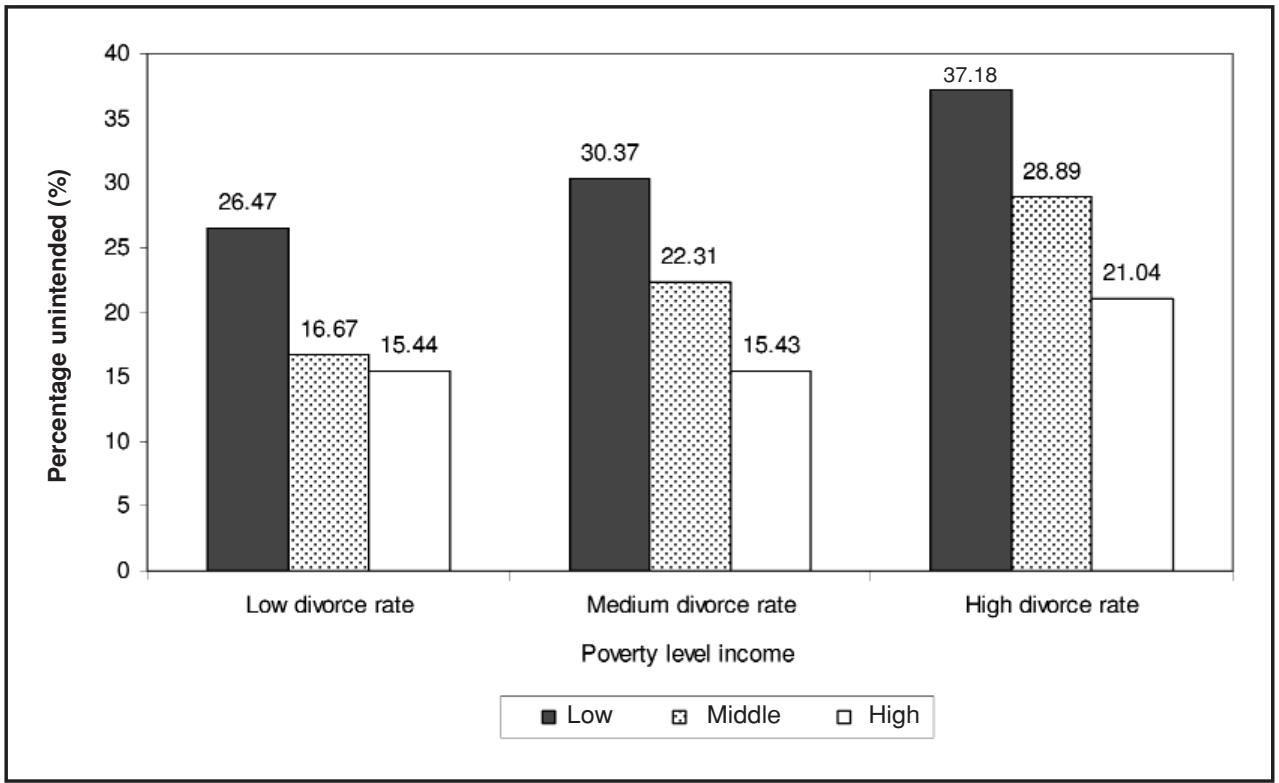

Figure 3 Percentage of unintended pregnancy among married women between the ages of 18 and 44 years by community family stability and poverty. $p<0.0001$

introduced contextual variables from the institutional theoretical model level that showed significance at the bivariate analysis. The variables 'family planning per 10000 women in need' and the 'abortions per 10000 women between 15 and 44 years' showed no significant association but improved the model fit (lowered the log

Table 1 Selected sample characteristics

\begin{tabular}{|c|c|c|c|}
\hline Variables & $n$ & $\%$ & $\begin{array}{l}\text { Weighted } \\
\%\end{array}$ \\
\hline \multicolumn{4}{|l|}{ Pregnancy intendedness } \\
\hline Intended & 4512 & 76.01 & 77.02 \\
\hline Unintended & 1424 & 23.99 & 22.98 \\
\hline \multicolumn{4}{|l|}{ Times married } \\
\hline 1 & 5087 & 85.47 & 84.79 \\
\hline $2+$ & 865 & 14.93 & 15.10 \\
\hline \multicolumn{4}{|l|}{ Parity } \\
\hline 1 & 1050 & 18.09 & 18.88 \\
\hline 2 & 2281 & 39.30 & 41.54 \\
\hline 3 & 1521 & 26.21 & 25.34 \\
\hline $4+$ & 952 & 16.40 & 14.40 \\
\hline \multicolumn{4}{|l|}{ Pregnancy order } \\
\hline 1 & 1317 & 22.13 & 23.52 \\
\hline 2 & 1754 & 29.47 & 30.16 \\
\hline 3 & 1359 & 22.83 & 22.38 \\
\hline 4 & 765 & 12.85 & 12.07 \\
\hline $5+$ & 757 & 12.72 & 11.87 \\
\hline \multicolumn{4}{|l|}{ Race } \\
\hline Hispanic & 1106 & 18.58 & 13.40 \\
\hline Non-Hispanic white & 3884 & 65.26 & 78.80 \\
\hline Non-Hispanic black & 728 & 12.23 & 6.44 \\
\hline Non-Hispanic other & 234 & 3.93 & 5.35 \\
\hline \multicolumn{4}{|l|}{ Respondent education } \\
\hline $1-8$ grade & 330 & 5.54 & 4.66 \\
\hline $9-12$ grade & 2630 & 44.19 & 44.69 \\
\hline $1-6$ years of college/university & 2801 & 47.06 & 47.28 \\
\hline $7+$ years of college/university & 191 & 3.21 & 3.38 \\
\hline \multicolumn{4}{|l|}{ Religion } \\
\hline None/no specific & 600 & 10.08 & 10.48 \\
\hline Protestant & 2973 & 49.95 & 49.53 \\
\hline Roman Catholic & 2160 & 36.29 & 35.70 \\
\hline Jewish & 109 & 1.83 & 1.91 \\
\hline Other & 110 & 1.85 & 2.38 \\
\hline \multicolumn{4}{|l|}{ Metropolis residence } \\
\hline Central cities of metropolitan areas & 1715 & 28.81 & 25.42 \\
\hline Suburban & 3054 & 51.31 & 53.70 \\
\hline Non-metropolitan areas & 1183 & 19.88 & 20.89 \\
\hline
\end{tabular}

likelihood). The 'proportion of women separated or divorced' was included for the community level theoretical model level. The community marital status was significantly related to pregnancy intendedness $(p<0.05)$.

\section{Discussion}

This study offers a unique contextual approach to examine the relationship between several layers of a theoretical model using multilevel logistic regression. Overall, married women of lower socioeconomic status, higher parity, whose husband did not intend the pregnancy or who were living in a community of marital instability had a higher probability of an unintended pregnancy.

The only marginally significant contextual variable in the model that increased the probability of unintended pregnancy was the proportion of women in the community who were separated or divorced. Previous research has found that a married woman was less likely to have a child when she lived in a community where there was a high rate of separated and divorced families. ${ }^{22}$ The results of this study also suggested that the higher the rate of abortions in the community, the lower the probability of unintended pregnancy. The higher the rate of family planning services per 10000 women in need, the lower was the probability of unintended pregnancy. Grady et al..$^{23}$ found that community family planning clinics promote effective contraception among married women. Similarly, Foster et al..$^{30}$ concluded that family planning services in low-income families in California are essential to provide the necessary education and access to address long-terms needs related to pregnancy prevention. However, a recent review of the quality of family planning services concluded that the service quality may vary significantly across sites. 31

One explanation for the reason why community characteristics were not significant in the multivariate models could be the correlation between unobserved individual characteristics and community factors. ${ }^{32}$ Those intrapersonal and interpersonal factors may enhance married women's vulnerability for a higher risk of unintended pregnancy, particularly when they are also exposed to unfavourable community and public policy factors. ${ }^{33}$ Previous research looking at the impact of community characteristics on a variety of outcomes (marital dissolution, fertility decisions, youth sexual activity) did not find direct causal influence of neighbourhood characteristics on the studied outcomes as well. 34,35 
Table 2 Multilevel logistic models results predicting unintended pregnancy among married women

\begin{tabular}{|c|c|c|c|c|c|c|c|c|c|c|c|}
\hline \multirow[b]{2}{*}{ Predictors } & \multicolumn{2}{|c|}{$\begin{array}{l}\text { Model } 1 \\
\text { Null Model }\end{array}$} & \multicolumn{3}{|c|}{$\begin{array}{l}\text { Model } 2 \\
\text { Theoretical levels } 1+2\end{array}$} & \multicolumn{3}{|c|}{$\begin{array}{c}\text { Model } 3 \\
\text { Theoretical levels } 1+2\end{array}$} & \multicolumn{3}{|c|}{$\begin{array}{c}\text { Model } 4 \\
\text { Theoretical levels } 1-4\end{array}$} \\
\hline & & & $\beta$ & SE & Sig & $\beta$ & SE & Sig & $\beta$ & SE & Sig \\
\hline Intercept & -1.20 & $* * * *$ & -0.5041 & $(0.3)$ & & -1.7268 & $(0.42)$ & $* * * *$ & -2.3396 & $(0.52)$ & $* * * *$ \\
\hline $\begin{array}{l}\text { INTRAPERSONAL } \\
\text { Age at conception } \\
\text { Parity }\end{array}$ & & & $\begin{array}{c}-0.00021 \\
0.1995\end{array}$ & $\begin{array}{l}(0.008) \\
(0.03)\end{array}$ & $* * * *$ & $\begin{array}{c}-0.00528 \\
0.2200\end{array}$ & $\begin{array}{l}(0.01) \\
(0.04)\end{array}$ & $* * * *$ & $\begin{array}{c}-0.00584 \\
0.2267\end{array}$ & $\begin{array}{l}(0.01) \\
(0.04)\end{array}$ & **** \\
\hline $\begin{array}{l}\text { Race } \\
\text { Non-Hispanic white } \\
\text { Other (ref) } \\
\text { Poverty level income } \\
\text { Education }\end{array}$ & & & $\begin{array}{l}-0.3668 \\
1.00 \\
-0.0010 \\
-0.01825\end{array}$ & $\begin{array}{l}(0.08) \\
(0.0002) \\
(0.01)\end{array}$ & $\begin{array}{l}* * * * \\
* * * *\end{array}$ & $\begin{array}{l}0.02278 \\
1.00 \\
-0.00060 \\
-0.00420\end{array}$ & $\begin{array}{l}(0.16) \\
(0.003) \\
(0.02)\end{array}$ & * & $\begin{array}{l}0.06860 \\
1.00 \\
-0.00061 \\
-0.00154\end{array}$ & $\begin{array}{l}(0.17) \\
(0.0005) \\
(0.02)\end{array}$ & * \\
\hline $\begin{array}{l}\text { Forced sex } \\
\text { No } \\
\text { Yes (ref) }\end{array}$ & & & $\begin{array}{l}-0.3530 \\
1.00\end{array}$ & $(0.15)$ & ** & $\begin{array}{l}-0.07810 \\
1.00\end{array}$ & $(0.2)$ & & $\begin{array}{l}-0.04835 \\
1.00\end{array}$ & $(0.2)$ & \\
\hline $\begin{array}{l}\text { Religion } \\
\text { None/no specific } \\
\text { Roman Catholic } \\
\text { Jewish/other } \\
\text { Protestant (ref) }\end{array}$ & & & $\begin{array}{l}0.4718 \\
-0.02494 \\
0.5036 \\
1.00\end{array}$ & $\begin{array}{l}(0.11) \\
(0.08) \\
(0.25)\end{array}$ & $\stackrel{* * *}{*}$ & $\begin{array}{l}0.2171 \\
-0.08300 \\
0.7125 \\
1.00\end{array}$ & $\begin{array}{l}(0.16) \\
(0.13) \\
(0.32)\end{array}$ & ** & $\begin{array}{l}0.1978 \\
-0.08449 \\
0.6706 \\
1.00\end{array}$ & $\begin{array}{l}(0.16) \\
(0.13) \\
(0.32)\end{array}$ & ** \\
\hline INTERPERSONAL & & & & & & & & & & & \\
\hline $\begin{array}{l}\text { Intact childhood family } \\
\text { Two biological parents } \\
\text { Other (ref) }\end{array}$ & & & $\begin{array}{l}-0.2900 \\
1.00\end{array}$ & $(0.08)$ & $\star * \star * *$ & $\begin{array}{l}-0.1722 \\
1.00\end{array}$ & $(0.1)$ & & $\begin{array}{l}-0.1641 \\
1.00\end{array}$ & $(0.1)$ & \\
\hline $\begin{array}{l}\text { Women's father's } \\
\text { education } \\
1-12 \text { years } \\
\text { Above } 12 \text { (ref) }\end{array}$ & & & $\begin{array}{l}-0.006381 \\
1.00\end{array}$ & $(0.01)$ & & $\begin{array}{l}0.007525 \\
1.00\end{array}$ & $(0.01)$ & & $\begin{array}{l}-0.1050 \\
1.00\end{array}$ & $(0.01)$ & \\
\hline $\begin{array}{l}\text { Husband's race } \\
\text { Non-Hispanic white } \\
\text { Other (ref) }\end{array}$ & & & & & & $\begin{array}{l}-0.4835 \\
1.00\end{array}$ & $(0.16)$ & $* \star \star$ & $\begin{array}{c}-0.459 \\
1.00\end{array}$ & $(0.16)$ & *** \\
\hline $\begin{array}{l}\text { Husband's religion } \\
\text { Protestant } \\
\text { Other (ref) }\end{array}$ & & & & & & $\begin{array}{l}0.001815 \\
1.00\end{array}$ & $(0.12)$ & & $\begin{array}{l}0.002135 \\
1.00\end{array}$ & $(0.12)$ & \\
\hline $\begin{array}{l}\text { Husband's education } \\
\text { Perceived husband's } \\
\text { intendedness }\end{array}$ & & & & & & -0.02847 & $(0.02)$ & & -0.03019 & $(0.02)$ & \\
\hline $\begin{array}{l}\text { Not intended } \\
\text { Intended (ref) }\end{array}$ & & & & & & $\begin{array}{l}3.2210 \\
1.00\end{array}$ & $(0.1)$ & $* * * *$ & $\begin{array}{l}3.2162 \\
1.00\end{array}$ & $(0.1)$ & $* * * *$ \\
\hline INSTITUTIONAL & & & & & & & & & & & \\
\hline $\begin{array}{l}\text { Family planning per } \\
10000 \text { women in need }\end{array}$ & & & & & & & & & -0.01771 & $(0.01)$ & \\
\hline $\begin{array}{l}\text { Abortions per } 10000 \\
\text { women aged between } \\
15-44 \text { years }\end{array}$ & & & & & & & & & -0.04291 & $(0.13)$ & \\
\hline COMMUNITY & & & & & & & & & & & \\
\hline $\begin{array}{l}\text { Metropolis residence } \\
\text { Central cities } \\
\text { Non-metropolitan } \\
\text { Suburban (ref) }\end{array}$ & & & & & & $\begin{array}{l}0.1876 \\
-0.2487 \\
1.00\end{array}$ & $\begin{array}{l}(0.13) \\
(0.11)\end{array}$ & * & $\begin{array}{l}0.1446 \\
-0.08140 \\
1.00\end{array}$ & $\begin{array}{l}(0.13) \\
(0.11)\end{array}$ & \\
\hline $\begin{array}{l}\text { Proportion of women } \\
\text { separated or divorced }\end{array}$ & & & & & & & & & 5.3614 & (2.5) & ** \\
\hline Estimated variances $\mu_{0} j$ & 0.0703 & ** & 0.04013 & $(0.02)$ & * & 0.03802 & $(0.03)$ & & 0.03121 & $(0.03)$ & \\
\hline $\begin{array}{l}\text { Goodness of fit } \\
-2 \text { log likelihood }\end{array}$ & 5487.8 & & & 4588.2 & & & 2988.2 & & & 2976.9 & \\
\hline $\begin{array}{l}\text { Individual sample size } \\
\text { County sample size }\end{array}$ & & & & $\begin{array}{r}4597 \\
63\end{array}$ & & & $\begin{array}{r}4597 \\
63\end{array}$ & & & $\begin{array}{r}4597 \\
63\end{array}$ & \\
\hline
\end{tabular}

Significance: ${ }^{*} p<0.1,{ }^{* *} p<0.05 ;{ }^{* * *} p<0.01,{ }^{* * *} p<0.001$. ref, reference; SE, standard error; Sig, significance.

Model 1: Null model.

Model 2: Intrapersonal and Interpersonal level variables.

Model 3: Added husband's characteristics and pregnancy intention with the community level variable, the place of residence.

Model 4: Included all four levels of the social ecology model.

Husbands' perceived pregnancy intendedness was another significant finding in this analysis, confirming previous research that suggested that acceptability of the mother's pregnancy intention was highly associated with the partner's attitude towards the pregnancy. ${ }^{18,19}$ Special efforts must be made to strengthen family planning services to include men in counselling and to build positive male attitudes toward reproductive health. ${ }^{30}$ 
The analysis revealed that the higher the woman's education level, the lower the risk of unintended pregnancy. Previous studies have shown a similar association between education and unintended pregnancy.2,4,36,37 Education raises the opportunity for career development and earning opportunities that are likely to compete with domestic and childrearing responsibilities. ${ }^{38}$ Since parity and race are related to socioeconomic status, women with a lower poverty level income had a higher parity and they are more likely to be non-white. These results support findings from previous research indicating that women who were black and reported a lower socioeconomic status had a higher odds of having an unintended pregnancy compared with those of white women of higher socioeconomic level.4,36,37

Of interest was the finding that Catholic women were not significantly more likely to have an unintended pregnancy compared with Protestant women. Earlier studies have hypothesised differences among religious groups to be related to social norms, differential sex roles, male-female communication patterns, and the differential use of physician-based versus other sources of contraceptives. 1,14,15

Intact status of childhood family and past history of forced first sex showed significant association only at the second statistical model (Table 2, Model 2). As the model became more complex, other variables appeared to be stronger predictors (husband pregnancy intendedness, for example).

In terms of the policy context, not much had changed in relative to policies that impacted women and their partners who are seeking to control their fertility from the time data were collected for this survey to a more recent time period. Indeed, recent published data related to the 1994-2001 time period concluded that there is almost no change in the overall rate of unintended pregnancies with a slight rise for married women compared with the NSFG data from 1995. Health insurance coverage rate during the compared years stayed at an average of $15 \%$ for the overall population, indicating persisting barriers to access to contraception and services. ${ }^{39}$ Funding for family planning services for the low-income population was cut and the services themselves were restricted. Based on the described similarities, the same analysis using the seventh cycle of the NSFG data should not be dramatically different from these findings; however, comparative analyses are planned using the 2006-2007 NSFG data expected to be released in 2010 .

Several limitations were identified in this study. Given their holistic perspective, ecological models are very complex. Due to the complexity of the model and the large number of independent variables involved, several of the predictor variables may not be significant in the prediction of unintended pregnancy among married women due to the multifaceted relation between the dependent variable and the independent variables and between the independent variables themselves. Another limitation of this study is the potential differences in cultural interpretation 7,40 of the construct of pregnancy intention. Asking women to recall pregnancy 'intention' or 'wantedness' from the past could also lead to recall bias. However, previous research has shown that women can accurately recall pregnancy information after an extended period of time. 41,42

Despite these limitations, this study utilised a unique approach to examine the contextual factors associated with pregnancy intendedness. Clinical implications include the need for practitioners to identify those women at risk for unintended pregnancies with considerations of community contextual factors in addition to personal risk factors. Also the findings suggest that participation of husbands and partners in reproductive education, decision making and family planning services should be increased. Special efforts must be made to strengthen family planning services to include men.

Future research in the planning stages includes a comparative analysis of the NSFG seventh data cycle (2006-2008) using an ecological approach. In addition, the construct of pregnancy intention needs to be further refined to determine racial/ethnic and other cultural interpretations. It is recommended that the social ecological model will be utilised to examine the contextual factors among married and unmarried women as well. Future population-based studies should also include data from the women's partners to enhance interventions. This study has identified factors to support and enhance changes in practice with the aim of reducing unintended pregnancies in the USA. As the health policy debate continues in the national arena, researchers, clinicians and policymakers need to come together to ensure coverage for preventative services such as family planning.

\section{Statements on funding and competing interests}

Funding This study was not funded. It was completed in partial fulfilment of the requirements for a dissertation research study for a $\mathrm{PhD}$ in nursing at the University of Massachusetts, Lowell, MA, USA.

Competing interests None identified.

\section{References}

1 Centers for Disease Control. DATA 2010 Focus Area: 09 Family Planning Objective 09-01. http://wonder.cdc.gov [Accessed 17 March 2010].

2 Finer LB, Hensaw SK. Disparities in rates of unintended pregnancy in the United States, 1994 and 2001. Perspect Sex Reprod Health 2006; 38: 90-96.

3 Department of Health and Human Services. Healthy People 2010: Understanding and Improving Health. Maternal, Infant, and Child Health, Volume II, Section 9 (2nd edn). 2000. http://www.healthypeople.gov/document/tableofcontents.htm\# parta [Accessed 1 June 2010].

4 Williams LB. Determinants of unintended childbearing among ever-married women in the United States: 1973-1988. Fam Plann Perspect 1991; 23: 212-215, 221.

5 Brown SS, Eisenberg L. Institute of Medicine. Committee on Unintended Pregnancy. The Best Intentions: Unintended Pregnancy and the Well-Being of Children and Families. Washington, DC: National Academies Press, 1995.

6 Afable-Munsuz A, Braveman P. Pregnancy intention and preterm birth: differential associations among a diverse population of women. Perspect Sex Reprod Health 2008; 40: 66-73.

7 Orr ST, James SA, Reiter JP. Unintended pregnancy and prenatal behaviors among urban, black women in Baltimore, Maryland: the Baltimore preterm birth study. Ann Epidemiol 2008; 18: 545-551.

8 Schwarz E, Smith R, Steinauer J, Reeves M, Caughey A. Measuring the effects of unintended pregnancy on women's quality of life. Conception 2008; 78: 204-210.

9 Green DC, Gazmararian JA, Mahoney LD, Davis NA. Unintended pregnancy in a commercially insured population. Matern Child Health J 2002; 6: 181-187.

10 Goldsmith KA, Kasehagen LJ, Rosenberg KD, Sandoval AP Lapidus JA. Unintended childbearing and knowledge of emergency contraception in a population-based survey of postpartum women. Matern Child Health J 2008; 12: 332-341.

11 McLeroy KR, Bibeau D, Steckler A, Glanz K. An ecological perspective on health promotion programs. Health Educ $Q$ 1988; 15: 351-377.

12 Green LW, Richard L, Potvin L. Ecological foundations of health promotion. Am J Health Promot 1996; 10: 270-281.

13 Gold RB, Stonefield A. Bush health "reform" agenda: implications for reproductive health. Guttmacher Rep Public Policy 2005; 8: 8-11

14 Goldscheider C, Mosher WD. Religious affiliation and contraceptive usage: changing American patterns, 1955-82. Stud Fam Plann 1988; 19: 48-57.

15 Goldscheider C, Mosher WD. Patterns of contraceptive use in the United States: the importance of religious factors. Stud Fam Plann 1991; 22: 102-115.

16 Althaus F. U.S. religious groups vary in patterns of method use, but not in overall contraceptive prevalence. Perspect Sex Reprod Health 1991; 23: 288-290. 
17 Olenic I. Women exposed to childhood abuse have elevated odds of unintended first pregnancy as adults. Fam Plann Perspect 2000; 31: 46-53.

18 Miller WB. Why some women fail to use their contraceptive method: a psychological investigation. Fam Plann Perspect 1986; 18: 27-32

19 Fischer RC, Stanford JB, Jameson P, DeWitt MJ. Exploring the concepts of intended, planned, and wanted pregnancy. J Fam Pract 1999; 48: 117-122

20 Joyce T, Kaestner R, Korenman S. The stability of pregnancy intentions and pregnancy-related maternal behaviors. Matern Child Health J 2000; 4: 171-178.

21 Rosenfeld JA, Everett K. Lifetime patterns of contraception and their relationship to unintended pregnancies. J Fam Pract 2000; 49: 823-828.

22 Billy JO. Moore DE. A multilevel analysis of marital and nonmarital fertility in the U.S. Soc Forces 1992; 70: 977-1011.

23 Grady WR, Klepinger DH, Billy JO. The influence of community characteristic on the practice of effective contraception. Fam Plann Perspect 1993; 25: 4-11.

24 Dailard C. Contraceptive coverage: a 10-year retrospective. Guttmacher Rep Public Policy 2004; 7: 6-9.

25 US Department of Health and Human Services. Family Planning. http://www.hhs.gov/opa/familyplanning/index.html [Accessed 17 March 2010].

26 Kelly JE, Mosher WD, Duffer AP, Kinsey SH. Plan and operation of the 1995 National Survey of Family Growth. Vital Health Stat 1 1997; 36: 1-89.

27 SAS Institute Inc., Cary, NC, USA. 1999. PROC NLMIXED requires Version 7 of the SAS System. Complete documentation is available on the web at http://www.sas.com/ techsup/download/stat/in the Postscript file nlmixed.ps.

28 Raudenbush SW, Bryk AS. Hierarchical Linear Models: Applications and Data Analysis Methods (2nd edn). Newbury Park, CA: Sage, 2002.

29 Henshaw SK. Unintended pregnancy in the United States. Fam Plann Perspect 1998; 30: 24-9, 46.

30 Foster DG, Biggs MA, Ralph LJ, Arons A, Brindis CD. Family planning and life planning reproductive intentions among individuals seeking reproductive health care. Womens Health Issues 2008; 18: 351-359.
31 Becker D, Koenig MA, Kim YM, Cardona K, Sonenstein FL. The quality of family planning services in the United States: findings from a literature review. Perspect Sex Reprod Health 2007; 39: 206-215.

32 Plotnic RD Hoffman SD. The effect of neighborhood characteristics on young adult outcomes: alterative estimates. Soc Sci Q 1999; 80: 1-18.

33 Krieger N, Rowley DL, Herman AA, Avery B, Phillips MT. Racism, sexism, and social class: implications for studies of health, disease, and well-being. Am J Prev Med 1993; 9(6 Suppl.): 82-122.

34 South JS, Baumer EP. Community effects on youth sexual activity. J Marriage Fam 2001; 63: 540-554.

35 South JS. The geographic context of divorce: do neighborhoods matter? J Marriage Fam 2001; 63: 755-766.

36 Gazmararian JA, Adams MM, Pamuk ER. Associations between measures of socioeconomic status and maternal health behavior. Am J Prev Med 1996; 12: 108-115.

37 Kost K, Forrest JD. Intentional status of U.S. births in 1998: differences by mothers' socioeconomic and demographic characteristics. Fam Plann Perspect 1995; 27: 11-17.

38 Birdsall N, Cochrane SH. Education and parental decision making: a two generational approach. In: Anderson L, Windham DM (eds), Education and Development. Lexington, MA: D C Heath, 1982.

39 Bernadette D, Proctor B, Hill Lee C. US Census Bureau, Current Population Reports, P60-231. Income, Poverty, and Health Insurance Coverage in the United States: 2005. Washington, DC: US Government Printing Office, 2006.

40 Blake SM, Kiely M, Gard CC, El-Mohandes AA, El-Khorazaty MN, NIH-DC Initiative. Pregnancy intentions and happiness among pregnant black women at high risk for adverse infant health outcomes. Perspect Sex Reprod Health 2007; 39: 194-205.

41 Dunne MP, Martin NG, Statham DJ, Pangan T, Madden PA, Heath AC. The consistency of recalled age at first sexual intercourse. J Biosoc Sci 1997; 29: 1-7.

42 Tilley BC, Barnes AB, Bergstralh E, Labarthe D, Noller KL Colton $\mathrm{T}$, et al. A comparison of pregnancy history recall and medical records. Implications for retrospective studies. Am J Epidemiol 1985; 121: 269-281.

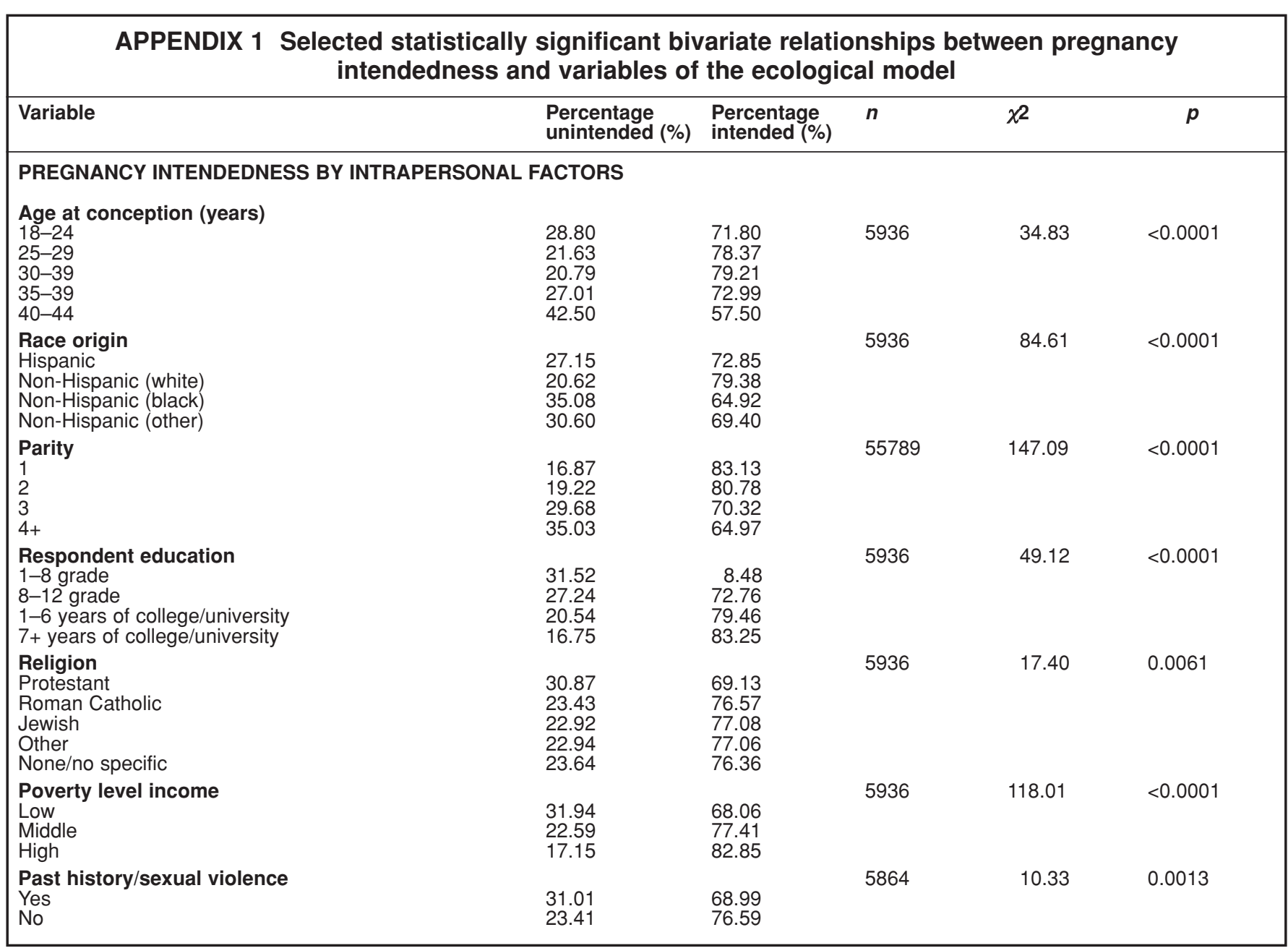




\begin{tabular}{|c|c|c|c|c|c|}
\hline \multicolumn{6}{|c|}{$\begin{array}{c}\text { APPENDIX } 1 \text { Selected statistically significant bivariate relationships between pregnancy } \\
\text { intendedness and variables of the ecological model (continued) }\end{array}$} \\
\hline Variable & $\begin{array}{l}\text { Percentage } \\
\text { unintended (\%) }\end{array}$ & $\begin{array}{l}\text { Percentage } \\
\text { intended (\%) }\end{array}$ & $n$ & $\chi^{2}$ & $p$ \\
\hline \multicolumn{6}{|c|}{ PREGNANCY INTENDEDNESS BY INTERPERSONAL FACTORS } \\
\hline $\begin{array}{l}\text { Husband intendedness } \\
\text { Yes } \\
\text { No }\end{array}$ & $\begin{array}{r}8.20 \\
66.03\end{array}$ & $\begin{array}{l}91.80 \\
33.97\end{array}$ & 5729 & 2091.37 & $<0.0001$ \\
\hline $\begin{array}{l}\text { Husband education } \\
\text { No formal } \\
1-12 \text { grade } \\
1-6 \text { years of college/university } \\
7+\text { years of college/university }\end{array}$ & $\begin{array}{l}37.50 \\
27.79 \\
20.19 \\
17.84\end{array}$ & $\begin{array}{l}62.50 \\
72.21 \\
79.81 \\
82.16\end{array}$ & 5908 & 52.00 & $<0.0001$ \\
\hline $\begin{array}{l}\text { Husband's religion } \\
\text { Protestant } \\
\text { Roman Catholic } \\
\text { Jewish } \\
\text { Other } \\
\text { None/no specific }\end{array}$ & $\begin{array}{l}29.68 \\
23.27 \\
23.32 \\
17.83 \\
22.14\end{array}$ & $\begin{array}{l}70.32 \\
76.73 \\
76.68 \\
82.10 \\
77.86\end{array}$ & 5889 & 15.94 & 0.0031 \\
\hline $\begin{array}{l}\text { Race } \\
\text { Hispanic } \\
\text { Non-Hispanic (white) } \\
\text { Non-Hispanic (black) } \\
\text { Non-Hispanic (other) }\end{array}$ & $\begin{array}{l}27.93 \\
20.63 \\
33.83 \\
31.02\end{array}$ & $\begin{array}{l}72.07 \\
79.37 \\
66.17 \\
68.98\end{array}$ & 5934 & 79.62 & $<0.0001$ \\
\hline $\begin{array}{l}\text { Respondent's father's education } \\
\text { No formal education } \\
1-12 \text { grade } \\
1-6 \text { years of college/university } \\
7+\text { years of college/university }\end{array}$ & $\begin{array}{l}29.80 \\
24.28 \\
20.47 \\
24.46\end{array}$ & $\begin{array}{l}70.20 \\
75.72 \\
79.53 \\
75.54\end{array}$ & 5684 & 12.23 & $<0.01$ \\
\hline $\begin{array}{l}\text { Intact status of childhood family } \\
\text { Two biological parents } \\
\text { Other }\end{array}$ & $\begin{array}{l}21.33 \\
29.71\end{array}$ & $\begin{array}{l}70.29 \\
78.76\end{array}$ & 5936 & 49.54 & $<0.0001$ \\
\hline \multicolumn{6}{|c|}{ PREGNANCY INTENDEDNESS BY INSTITUTIONAL FACTORS } \\
\hline $\begin{array}{l}\text { Abortions per } 10000 \text { women aged } \mathbf{1 5}-\mathbf{4 4} \text { years } \\
0 \\
>0 \text { and }<5 \\
\geq 5 \text { and }<20 \\
\geq 20 \text { and }<40 \\
\geq 40\end{array}$ & $\begin{array}{l}22.80 \\
21.16 \\
17.65 \\
24.28 \\
26.56\end{array}$ & $\begin{array}{l}77.19 \\
78.84 \\
82.35 \\
75.72 \\
73.44\end{array}$ & 5508 & 19.39 & $<0.001$ \\
\hline $\begin{array}{l}\text { Family planning service providers per } 10000 \\
\text { women age in need: county } \\
\text { Low } \\
\text { Middle } \\
\text { High }\end{array}$ & $\begin{array}{l}25.03 \\
23.06 \\
23.26\end{array}$ & $\begin{array}{l}74.97 \\
76.94 \\
76.74\end{array}$ & 5508 & 2.30 & $<0.5$ \\
\hline $\begin{array}{l}\text { Proportion household with public assistance } \\
\text { income:county } \\
\text { Low } \\
\text { Middle } \\
\text { High }\end{array}$ & $\begin{array}{l}20.49 \\
23.65 \\
27.02\end{array}$ & $\begin{array}{l}79.51 \\
76.35 \\
72.98\end{array}$ & 5512 & 21.72 & $<0.0001$ \\
\hline \multicolumn{6}{|c|}{ PREGNANCY INTENDEDNESS BY COMMUNITY FACTORS } \\
\hline $\begin{array}{l}\text { Place of residence (metropolitan) } \\
\text { Metropolitan } \\
\text { Suburban } \\
\text { Non-metropolitan }\end{array}$ & $\begin{array}{l}28.28 \\
22.35 \\
22.01\end{array}$ & $\begin{array}{l}71.72 \\
77.65 \\
77.99\end{array}$ & 5936 & 24.25 & $<0.0001$ \\
\hline $\begin{array}{l}\text { Unemployment rate } \\
\text { Low } \\
\text { Middle } \\
\text { High }\end{array}$ & $\begin{array}{l}21.62 \\
22.12 \\
27.45\end{array}$ & $\begin{array}{l}78.38 \\
77.88 \\
72.55\end{array}$ & 5512 & 21.31 & $<0.0001$ \\
\hline $\begin{array}{l}\text { Unemployment rate: female } \\
\text { Low } \\
\text { Middle } \\
\text { High }\end{array}$ & $\begin{array}{l}20.52 \\
23.93 \\
26.70\end{array}$ & $\begin{array}{l}78.48 \\
76.07 \\
73.30\end{array}$ & 5512 & 19.42 & $<0.0001$ \\
\hline $\begin{array}{l}\text { Proportion aged } 25+\text { years with no high school } \\
\text { diploma or equivalent } \\
\text { Low } \\
\text { Middle } \\
\text { High }\end{array}$ & $\begin{array}{l}20.18 \\
24.58 \\
26.33\end{array}$ & $\begin{array}{l}79.82 \\
75.42 \\
73.67\end{array}$ & 5512 & 20.54 & $<0.0001$ \\
\hline $\begin{array}{l}\text { Proportion females separated or divorced } \\
\text { Low } \\
\text { Middle } \\
\text { High }\end{array}$ & $\begin{array}{l}19.15 \\
22.30 \\
29.63\end{array}$ & $\begin{array}{l}80.85 \\
77.70 \\
70.73\end{array}$ & 5512 & 58.97 & $<0.0001$ \\
\hline
\end{tabular}

